\title{
Sikh Community as an Ethnic Minority in Patna, Bihar
}

\author{
Mahima Mehra
}

\begin{abstract}
The capital of Bihar - Patna, is one of the holiest cities in Sikh history. Despite rich historical and religious significance, the population of Sikhs in Patna is merely $0.09 \%$ of the total population. The Sikh minority in the Bihar capital is one of the handful minorities of India who have never "claimed" a minority status or any compensation for their community from the government. However, the community continues to preserve its ethnic behavior and social symbols to date. This paper aims to analyze the existence of social institutions that support the formation of the Sikh community as ethnicity in Patna, Bihar. It also touches briefly on the reasons behind the lack of agency and demand for greater minority representation. Interviews were taken from 100 respondents in January 2019 in the capital city of Patna, Bihar in India. Age was taken as a criterion for inclusion. The findings of the study show that minority behavior is not the same everywhere. The ethnicity of the community is maintained by the continuity of symbols of lifestyle such as dietary habits, attire, the teaching of Gurumukhi in school and colleges, and trade activities. A reasonable explanation can allude to the very foundations of the Sikh community which upholds ideals of bravery and resilience. Begging or lobbying is a mandate prohibited by the very religion which protects them. However, the younger population shows a shift towards the general trend and is moving away from the economic set up of establishing business and of looking at the Gurudwara as an intersection of political and social rights. A change in the coming decade is inexorable. This research can be used as a model to understand the behavior of other minorities in India or elsewhere. It provides a better-looking glass to understand subaltern behavior. Additionally, it also shows variations in the status of communities. The Sikh community, a majority religion in most of Northern India, is a minuscule minority in Patna's Capital city with rich Sikh history.
\end{abstract}

Keywords: Ethnicity, Gurudwara, Minority, Sikhism, Social Institutions

\section{INTRODUCTION}

The Oxford Short Introduction [1] describes Sikhism as the newest and the youngest of all world religions. Its media image is predominantly male, and reports often suggest that it is a religion preoccupied with swords and turbans.

Anyone who has read a fair amount of Sikh history would know that Bihar holds supreme importance in the history of Sikh civilization. Guru Nanak, the founder of the religion, visited the capital city Patna (Pataliputra) during his travels. Guru Teg Bahadur was on his way to Assam when his son,

Revised Manuscript Received on August 13, 2020.

* Correspondence Author

Mahima Mehra*, Department of Sociology, Lady Shri Ram College for Women, India. E-mail: mahimamehra1998@gmail.com

(c) The Authors. Published by Blue Eyes Intelligence Engineering and Sciences Publication (BEIESP). This is an open access article under the CC BY-NC-ND license (http://creativecommons.org/licenses/by-nc-nd/4.0/)
Guru Gobind Singh, was born at Patna. It is hardly surprising then, that Patna or Patna Saheb is a renowned pilgrimage for the Sikhs. Some relics of the tenth Guru are preserved in the Patna Sahib. Among them is a Pangura (cradle) with four stands covered with Golden plates. Guruji during his childhood used to sleep in this cradle. Moreover, four iron arrows, the sacred sword of the Master, and a pair of his sandals are also preserved in the pilgrim. Understandably, after the partition of India in 1947, many Sikhs settled in Patna. Gurudwara Patna Sahib is regarded as the center for propagating Sikhism in the East. As history would have it, Takht Sri Patna Sahib is the second accepted and acknowledged Takht of the Sikhs. Sikhism is an important religion taught in the schools and universities of Bihar. The Takht witnesses massive tourist footfall each year. In 2017 alone, 3.35 crores tourists visited Patna owing to the Buddhists and Sikh pilgrims in the city [2]. However, the numbers remain limited to tourism. The historical background and religious sanctity attached to Patna would make a reader think that a good number of Sikhs would choose to settle in Patna and form a majority religion. The demographics, on the contrary, show a very different picture. As per the 2011 census of India [3]; the total population of Patna is $58,38,465$ persons, out of which $86 \%$ are Hindus, followed by $12.2 \%$ Muslims. Sikhism only forms the fourth largest or the largest minority religion with a low rate of $0.09 \%$. This means that there are roughly 4,670 Sikhs in Patna.

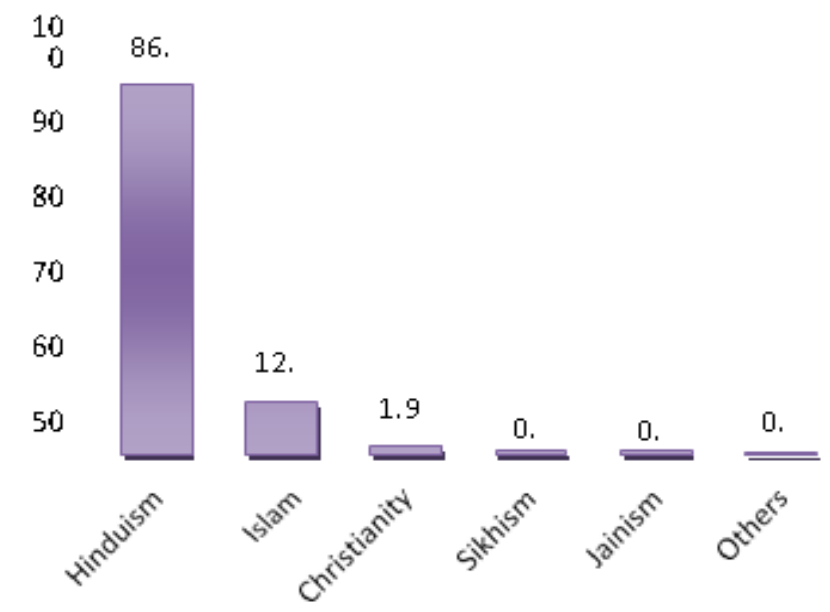

Figure 1: Shows the population of Patna divided by religious composition. This data has been taken from the Census of India 2011.

This paper looks at the ethnic minority status of Sikhs in Patna by using two vantage points.

1. Existing social institutions which support the formation of the Sikh community as an ethnicity 

greater minority representation

\section{LITERATURE REVIEW}

Diana L Eck's book “India - a Sacred Geography [4]" constructs the Indian landscape essentially as sacred geography. According to her, the land of India bears traces of the gods and the footprints of the heroes. Since Patna's importance for the Sikh community comes primarily from the shrine it holds and the history associated with the pilgrim; L Eck's study becomes extremely important.

"The Sikhs - Ideology, Institutions, and Identity [5]" brings together essays by J S Grewal. Spanning over four decades, it presents a comprehensive and authoritative account of key aspects of Sikh tradition from Guru Nanak to the present times. He has highlighted the question of martyrdom in Sikh history and discussed other relevant topics like Dashwant [6], the Prem Sumarg [7], and Initiation in Sikhism [8]. He ends his discussion by highlighting contemporary controversies in current Sikh literature. The book ends with an extremely comprehensive glossary on Sikh terminology - some of which have been used in the pages of this research.

The paper, "Sikhs and Sikhism in eastern and north-eastern India [9]" by Himadri Banerjee discusses the lifestyle and status of Sikh communities in east and northeastern states such as Orissa, Bengal, Assam, and Meghalaya. In the early 1980s, any research on the Sikh past or pointing out Sikhism's intimate link with the wider Indian milieu was not considered a subject of any serious scholarly inquiry. Sikhs were widely highlighted and viewed as a secessionist force. This also explains why so many of the books I found were only discussing the Khalistan movement and there was such little academic literature on institutions within Sikhism and the way of life of the Sikh community - a problem which would never have arisen in Hinduism studies. Furthermore, she discusses the rural-urban differences between the Sikhs in Assam and Sikhs in Kolkata. There is a sort of animosity between the Bengali Sikhs and Akali in Punjab due to the shifting nature of power structures. Another point she makes is related to the indigenous Bihari Sikhs. They belong to an ethnic group that is distinctly different from that of the Sikhs of Punjab. These were people who embraced Sikhism during the time of the ninth guru and may not be from Punjabi descent. This argument provides a context to the Asli-Nakli status of Sikhs, used in the arguments ahead.

\section{METHOD AND APPROACH}

This Research Uses Sampling Method Where A Small Sample Of Respondents From Various Age Groups Was Taken To Be Representative Of The Entire Population. Interviews Were Taken From 100 Respondents In January 2019 In The Capital City Of Patna, Bihar In India. Due To The Qualitative Approach Of The Study, indicators were marked based on the economic, social, and political behavior of the population. These indicators were used to evaluate interviews and focused group discussions of/with respondents. Inclusion Criteria: Age was taken as a criterion for inclusion. 50 respondents were under the age of 18 and
2. The reasons behind the lack of agency and demand for

the other 50 were over the age of 18 . Gender was not taken as a parameter for choosing respondents.

\section{DESCRIPTIVE ANALYSIS}

Table 1: Demographic Analysis of the population as recorded. Note that in the case of Under 18 respondents, their desire to get married and desire to own business was taken instead of status at the time of the survey. This was done to predict a change in the coming decade.

\begin{tabular}{|c|c|c|}
\hline \multicolumn{3}{|c|}{ PHIC ANALYSIS } \\
\hline Variables & $\begin{array}{c}\text { Above } \\
18 \\
\text { Years } \\
\text { of Age } \\
(\%) \\
n=50\end{array}$ & $\begin{array}{c}\text { Under } 18 \text { Years } \\
\text { of Age }(\%)\end{array}$ \\
\hline Married & 93 & \#\#\#\#\#\#\# \# \\
\hline $\begin{array}{l}\text { Secondary } \\
\text { Education }\end{array}$ & 70 & \#\#\#\#\#\#\#\# \# \\
\hline $\begin{array}{l}\text { Business } \\
\text { Owner }\end{array}$ & 84 & \#\#\#\#\#\#\# \# \\
\hline $\begin{array}{l}\text { Punjabi } \\
\text { Speaker }\end{array}$ & 100 & \#\#\#\#\#\#\# \# \\
\hline Migrant & 21.7 & \#\#\#\#\#\#\# \# \\
\hline
\end{tabular}

The following findings are drawn from the interviews and focused group discussions which have been done with the sample population of 100 respondents; composed of students, tourists, Gurudwara administrative officials, businessmen and businesswomen, and residents of Chitkohra colony in Patna. The findings have been divided on a structural-functional basis - by the functions of the social institutions.

\section{RESULT}

\section{A. Kinship, family \& economic institutions}

Patna is the birthplace of the tenth Sikh Guru, Guru Gobind Singh. This is a major pull-factor for the migration of the Sikhs in Patna. As informed by respondents, many of them migrated to Patna pre-partition and some of them came after the Partition. The others are born and brought up in Patna. But about $80 \%$ of the Sikhs went back to Punjab after the 1984 riots due to gruesome atrocities faced by their community.

The remaining population stayed in Patna and now constitutes the total Sikh population of the City - a mere $20 \%$ of the original number. Over $84 \%$ of Sikhs in Patna are engaged in business. The others are employed in the service sector. The Gurudwara also employs a good number of Sikhs. The types of businesses that are most common among the Bihari Sikhs are transport, hardware and cloth. Sikh women living in Punjab wear salwar kameez and men wear Kurta and turban. In the case of the Bihari Sikh women, they wear both saree and salwar kameez. Though older men prefer ethnic attire, the younger population has adopted Western clothing.

Published By:

Blue Eyes Intelligence Engineering DOI:10.35940/ijmh.L1089.0841220

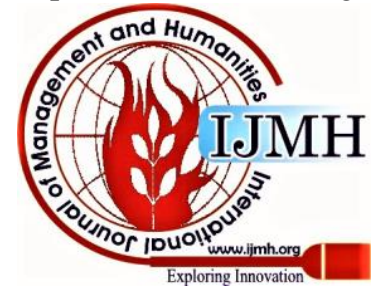


Wearing a turban is a must for men. Men are supposed to keep long hair. All men, women and alike actively take part in organized religion. Historically, Sikhism emerged as a form of emancipation from Caste binaries and the compartmentalization of the Varna system. The surnames Singh and Kaur were allotted to all Sikh men and women to eliminate caste identity from the social order. However, this is far from the truth. The Khatris, Jats and Rajput Sikhs are considered upper caste or pure Sikhs. Surnames like Ahluwalia, Bedi, Sodhi and Sandhu occupy a higher status in the caste hierarchy than Mazhabi Sikhs or Ramgharia Sikhs. Sikh castes in Patna consider converts as "fake" (Nakli) Sikhs and often distinguish themselves as pure or indigenous (Asli) Sikh. These "fake" Sikhs are lower caste men or women from other religions who became associated with the Gurudwara and adopted Sikhism for social and economic upward mobility as well as for aid from the government in the educational and employment sector. There is another indicator of caste present. There is endogamy in terms of Religion, but exogamy in terms of Gotra. Due to the scarcity of different Sikh lineages within Bihar, most girls get married outside of Bihar. Oppositely, Daughters-in-law are brought in from Jharkhand, Haryana, and Punjab. While Punjabi continues to be a majority language, not all Bihari Sikhs speak in Punjabi. Many Sikhs in Patna speak Bihari, Hindi, Punjabi, or Bihari-Punjabi. Punjabi is taught in Patna Sahib Gurudwara to children who come for schooling. The community is open to love marriage, though they do not prefer it. There has been a fusion of food and dietary habits of Punjabi and Bihari over the years. Non- Sikhs in Patna have whole-heartedly accepted the flavors of Punjab, just like most of the other Indian states. Tandoori Roti, Dal Makhani, Laccha Parantha, Rajma, Kadhai Paneer, and Channa Masala are popular dishes all over Patna. Sikhs have also tried to preserve their indigenous flavors. Respondent Dr. Sudarshan Singh fondly remembered, "Punjabi Tadka" loaded with garlic, ginger, chilies, and oil; added in dal and various curries peculiar to Punjab. Meals at home include Punjabi dal \& sag as well as Bihar's Litti Chokha \& Sattu. The Sikh population is scattered in different parts of Patna. Chitkohra is one of the most prominent areas with a good amount of Sikh cluster living there. The area near the Chitkohra Gurudwara has come to be known as the Punjabi Colony.

\section{B. Religious and Political Institutions}

Despite being a minuscule silent minority of Bihar, the Sikhs in Patna have never faced subjugation. This is mostly due to the Gurudwara's stronghold in the city which made the indigent less vulnerable in society. The Gurudwara adopts and employs the destitute. The Langar facility of the shrine takes care of their diet and the verandas and living quarters of the Gurudwara provide the shelter. The volunteers taught languages such as Punjabi and Hindi as well as other subjects like Mathematics and Science. The Gurudwara is not just a means of sustenance and livelihood, but also an important stepping stone for gaining administrative and social reform at the State Level. Managing Body of the Gurudwara has a say in changing the discourse of Sikh reforms under the Janata Dal government. For any actual reform to take place such as choosing a Sikh representative in the State Minority Commission as well as conducting elections for internal affairs within the Patna Sahib, the Amritsar Takht Sri Harmandir Sahib wields a herculean amount of power. There is an interesting turn to the story. Due to the absence of Sikh representation in the State Minority Commissions for many decades, a good share of the population has forgotten that it existed in the first place. Besides the State Minority Commission, the Headmaster's seat at the Sikh College and the fifteenth seat of the administrative body are also empty. The positions which did not have a Sikh criterion have been filled by representatives of other religions - primarily Hinduism.

\section{Educational Institutions}

With the Gurudwara Reform Act [10] the Gurudwara complex itself was expanded to accommodate a greater breadth of educational oriented activities. While most Gurudwaras had space for teaching and learning, much of this activity now reflected the normative standards articulated by the Tat Khalsa. While smaller Gurudwaras may have housed a modest library with a few books, larger Gurudwaras ran schools, offered courses in Khalsa history, Gurmat, and Gurmukhi for members of the community. Educational space is particularly important for Sikhs diaspora as it provides a formal link with Sikh culture and learning that may otherwise be absent for second and subsequent- generation Sikhs living outside Punjab. In Patna, the Gurudwara owns two schools and one college with Sikh minority characters. Gurumukhi the language of the Sikh religion is taught in all these institutions.

\section{CONCLUSION}

Whenever there is a discussion on minority, a very one-dimensional view of oppression and subordination forms the major part of the discussion. The Sikh minority becomes an exception to the rule. The Sikhs in Patna identify themselves as a minority but do not feel victimized because of it. This can be attributed to two factors. Their religion has protected them from disrespect and oppression from other religious communities. Religious institutions have provided economic, cultural, and social capital; and hence, there is no need to feel inadequate. Moreover, the pride associated with being a Sikh does not allow members of the community to beg or plead. There is a conscious realization that they have to provide for themselves and wherever they are unable to, the Gurudwara provides for them. The Sikh community is itself very elite. They always have occupied a superior status in the caste/class hierarchy. The Sikhs, though less visible in Patna are treated with respect due to their identity as a "Sardaar." Hence, the primary indicators of a subjugated minority, such as unequal treatment and feeling of subordination do not apply to them in the first place. Sikh indigenous culture has been preserved over the years by the families living in Patna.

In the case of Chitkohra, they have even formed a geographical cluster and continue to practice life as it was in Punjab.

Published By:

Blue Eyes Intelligence Engineering

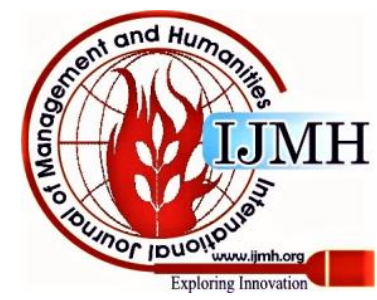


The community engages in business, entrepreneurship, or takes up white-collar jobs in the industry. There is a general trend among the younger population (below the age of 18) to stir away from the age-old lifestyle practices. There is an inclination to migrate to metropolitan cities or take up clerical jobs in Patna. There is also a desire to contest for political representation, one which wasn't seen in the older population. With the change in generation, a shift in age-old paradigms is inexorable. The status, lifestyle, and political representation of Sikhs as an ethnic minority are bound to change in the coming decade. This study attests to the fact that minority status does not equate to victimization and it is incorrect in pragmatic sciences to assume so. It is important to study the history, status, and life chances of the community in question; before drawing up a dogmatic notion such as this one. For any successful anthology on a given community to be conducted; conducting a successful historical analysis is imperative. The status and numbers of Sikhs as it is today in Patna is owed to the events of the past. The 1947 Partition, riots of 1985, and finally, the formation of Jharkhand in 2000 shaped their institutions and lifestyles to a great extent. We can also conclude that the basic structure of community life is the same everywhere. This a common thread that binds the community - in this case being a religion. There are economic, political, social, and familial institutions that contribute to upholding the community. Using this model, any community - no matter how complex, can be broken down and analyzed in its entire entirety. This research can be used as a model to understand the behavior of other minorities in India or elsewhere. Comparing the behavior of the Sikh minority in Patna to that of the Sikh minority in Britain would be an interesting starting point for comparative research. The second minority religion in Patna with a pilgrim history is Buddhism. Juxtaposing the life and status of Bihari Buddhists and that of Bihari Sikhs could make for another strong ethnology. A third take could be comparing the behavior of South Asian minorities to that of South American. That, I leave to the reader. Whatever may be the future of this research, I hope it continues to provide a better looking glass to understand subaltern behavior in Bihar or elsewhere and continues to break conventional definitions of minorities and ethnicities.

\section{REFERENCES}

1. Nesbitt, Eleanor. "Sikhism" - a very short introduction. Great Britain: Oxford University Press, 2005.

2. https://timesofindia.indiatimes.com/toireporter/author-Piyush-Tripathi -479250993.cms. Times of India. Feb 9, 2018. https://timesofindia.indiatimes.com/city/patna/2017-tourist-footfallhighest-in-five-years/articleshow/62841356.cms (accessed March 30, 2019).

3. Census 2011. n.d. https://www.census2011.co.in/data/religion/district/82-patna.html (accessed April 5, 2019).

4. Eck, Diana L. India - A Sacred Geography. New York: Random House, 2012.

5. Grewal, J S. The Sikhs - Ideology, Institutions and Identity . New Delhi: Oxford University Press, 2009.

6. Ibid.

7. Ibid.

8. Ibid.

9. Banerjee, Himadri. "SIKHS AND SIKHISM IN EASTERN AND NORTH-EASTERN INDIA." Institute of Sikh Studies. n.d. https://sikhinstitute.org/sikhs_living_outside/5-himadribanerjee.html (accessed March 27, 2019).
10. Nayar, Baldev Raj. Minority Politics in Punjab. New York: H Wolff Book Mfg.Co.Inc, 1996.

\section{AUTHORS PROFILE}

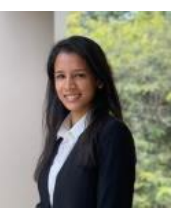

Mahima Mehra, Currently working with a public health organization based out of New Delhi, Mahima Mehra graduated with honors from the Department of Sociology, Lady Shri Ram College for Women in 2019. This paper forms a part of her dissertation on Bihari Sikhs in Patna. A true sociologist at heart, she is an avid reader and passionate about cultural sciences and development studies. She also actively pursues law and advocacy. In the past, she has worked with the Government of India in the capacity of a research intern. Her previous papers include Covid-19 \& Public Health Laws, Impact of Capitalism on Religion and the Status of women in Racial America and Casteist India. She currently holds several offers from prestigious universities like the University of Edinburgh, University of Sussex and IHEID Geneva for a postgraduate degree in Social Anthropology. She was also selected on merit for a master's degree at the Delhi School of Economics, which she turned down due to her professional commitments.

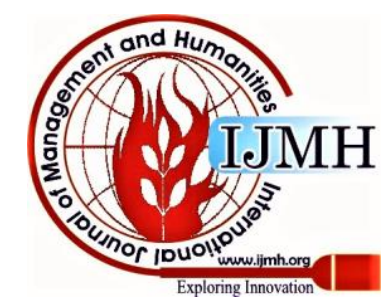

